\title{
A note on the effect of charcoal supplementation on the performance of Big 6 heavy tom turkeys
}

\author{
T. Majewska, D. Pyrek and A. Faruga \\ Department of Poultry Science, University of Warmia and Mazury in Olsztyn \\ Oczapowskiego 5, 10-718 Olsztyn, Poland
}

(Received 27 November 2000; revised version 9 November 2001; accepted 31 January 2002)

\section{ABSTRACT}

The experiment was conducted on 204 Big 6 heavy tom turkeys. One-day-old chickens were allocated to two feeding groups, each with threc replicates of 34 birds. All of the birds were fed identical granulated standard feeds in a three-stage system. The control birds were fed unsupplemented feed, the birds in the treatment group received a feed supplemented with pulverized hardwood charcoal at a dose of $3 \mathrm{~kg} / \mathrm{ton}$. Charcoal was given from day one of life for the entire period of rearing.

The use of charcoal had a beneficial effect on performance. After 18 weeks of rearing, turkeys given charcoal-supplemented feed were $5.9 \%$ heavier (on average $870 \mathrm{~g}$ ) and had a $6.5 \%$ better feed conversion ratio than the control birds. Survival in the group receiving charcoal was $99 \%$ as compared with $87.3 \%$ in the control group. The crude protein content of the breast muscles of the experimental group increased significantly. The European Production Index equaled 393 for the control group and 504 for the charcoal-supplemented group.

KEY WORDS: charcoal-supplemented, turkeys, performance

\section{INTRODUCTION}

Charcoal obtained through dry distillation of hardwood contains about $96 \%$ pure charcoal and $4 \%$ of other mineral compounds. The mineral compounds in charcoal are in organic form. When they are dissolved in water they act as biocatalysts that can contribute to regulating metabolic processes, maintaining the proper osmotic potential of body fluids, activating enzymes, hormones and antibodies.

Charcoal has enormous absorptive properties. It acts curatively on the gastrointestinal tract, absorbing gases such as hydrogen sulphide and ammonia that 
are formed there, bacterial toxins as well as mycotoxins produced by fungi (Anjaneyulu and Rao, 1993; Edrington et al., 1997; Shareef et al., 1998). According to Garwacki and Wiechetek (1998) the use of charcoal is also beneficial in cases of poisoning by such compounds as alkaloids, phenols, glycosides, and even strychnine and potassium cyanide. Charcoal is not digested in the GI tract and binds various substances through physical interactions regardless of whether they are ionized or not. By binding ammonia, charcoal protects the intestines from alkalization. It prevents intestinal infections and stops the diarrhoea caused by them by adsorbing and eliminating the germs with the faeces, but it is not bactericidal. The minerals contained in charcoal form bases with water, lower the surface tension of the digesta, emulsify fat, thereby support liver function and enable the digestion and assimilation of fat. The beneficial effect of charcoal on humans and animals has been known for a long time. Its favourable influence on increasing the body weight of broiler chickens, their survival and feed utilization was described by Anjaneyulu and Rao (1993), Edrington et al. (1997) Shareef et al. (1998) and Majewska et al. (1999)

The purpose of this study was to examine the effect of hardwood charcoal on the performance of Big 6 heavy tom turkeys.

\section{MATERIAL AND METHODS}

The experiment was conducted on the poultry farm of the University of Warmia and Mazury in Olsztyn. The experimental material comprised 204 one-day old heavy Big 6 tom turkeys purchased from the Canadian company Cuddy. The chickens were allocated to two feeding groups, each with three replicates of 34 birds and were maintained for 18 weeks on litter. The birds in both groups were fed identical granulated standard feeds in a 3 -stage system, IB-1, IB-2, IB-3. Feed composition and nutrient value are presented in Table 1 . The birds in group I (control) did not receive charcoal, those in group II received pulverized hardwood charcoal from the first day of life during the entire period of rearing as a feed supplement in an amount of $3 \mathrm{~kg}$ per ton of feed.

All of the birds were weighed individually at the end of weeks 5, 7, 11, 15 and 18 of life. Feed consumption was determined per group per week, culling and mortality were recorded daily. After the end of the experiment 9 birds from each group with body weights close to those of the group average were slaughtered and dissected. Breast meat was immediately minced, homogenized and samples were subjected to chemical and physicochemical analysis. The dry matter, crude protein, crude fat and crude ash contents were determined by conventional methods. Water holding capacity was determined by the Grau and Hamm method (1953), colour on the basis of the spectrometric method of Kortz et al. (1968), 
Composition and nutritive value of feed mixlures, $\mathrm{g} / \mathrm{kg}$

\begin{tabular}{|c|c|c|c|}
\hline \multirow{4}{*}{ Specification } & \multicolumn{3}{|c|}{ Feed mixtures } \\
\hline & IB-1 & IB-2 & IB-3 \\
\hline & \multicolumn{3}{|c|}{ Pcriod of feeding (wceks of life) } \\
\hline & $0-7$ & $8-11$ & $12-18$ \\
\hline Wheat & 310.0 & 370.0 & 624.0 \\
\hline Maize & 100.0 & 100.0 & 100.0 \\
\hline Soyabcan oilmeal $(46 \% \mathrm{CP})$ & 411.4 & 353.6 & 150.0 \\
\hline Meat and bone meal $(58 \% \mathrm{CP})$ & 100.0 & 70.0 & 40.0 \\
\hline Soya oil & 40.0 & 60.0 & 50.0 \\
\hline $\mathrm{NaCl}$ & 0.6 & 0.6 & 1.0 \\
\hline Dicalcium phosphate & 21.0 & 23.0 & 19.0 \\
\hline Limestone & 2.0 & 7.0 & 2.5 \\
\hline DL-Met & 2.5 & 2.8 & 1.5 \\
\hline Lys & 2.5 & 3.0 & 2.0 \\
\hline Mineral-vitamin premix & 10.0 & 10.0 & 10.0 \\
\hline Crude protein & 280.0 & 240.0 & 160.0 \\
\hline $\mathrm{ME}, \mathrm{MJ} / \mathrm{kg}$ & 11.86 & 12.72 & 13.35 \\
\hline Crude fibre & 28.0 & 33.0 & 35.0 \\
\hline Met & 7.1 & 5.9 & 3.7 \\
\hline Lys & 17.0 & 14.0 & 10.0 \\
\hline $\mathrm{Ca}$ & 13.5 & 11.7 & 9.9 \\
\hline Available P & 7.0 & 5.5 & 4.4 \\
\hline
\end{tabular}

acidity on the basis of $\mathrm{pH}$ of aqueous homogenates using a Radiometr $\mathrm{pH}$-meter with a combined electrode. Blood for routine haematological and biochemical tests was sampled from the slaughtered birds. The red blood cell (RBC) and white blood cell (WBC) counts were determined by the chamber method, the haemoglobin content $(\mathrm{Hb})$ was assayed colorimetrically, haematocrit value $(\mathrm{Ht})$ by the microhaematocrit method. Glucose, protein and cholesterol levels were determined using Alpha Diagnosticks and Pointe Scientific kits and an Epoll 20 photometer.

The European Production Index (EPI) was calculated using the formula:

$$
\mathrm{EPI}=\frac{\text { body weight }(\mathrm{kg}) \times \text { survival }(\%)}{\text { days of rearing } \mathrm{x} \text { feed conversion ratio }(\mathrm{kg} / \mathrm{kg})} \times 100
$$

The results were subjected to statistical analysis using variance analysis in orthogonal and nonorthogonal models using Stat 1 software (Mikołajczak, 1993). 


\section{RESULTS AND DISCUSSION}

A beneficial effect of added charcoal on body weight was noted starting from the fifth week of rearing (Table 2). At the end of the experiment after 18 weeks, the birds in the group receiving $0.3 \%$ charcoal were significantly, 870 g, i.e. $5.9 \%$ $(\mathrm{P}<0.01)$, heavier than those in the control group. The addition of charcoal favourably affected the feed conversion ratio (Table 2 ). Tom turkeys receiving

TABLE 2

Body weight ( $\mathrm{kg}$ ) of turkeys, feed conversion ratio (FCR) $\mathrm{kg} / \mathrm{kg}$, mortality and culling, \%

\begin{tabular}{|c|c|c|c|}
\hline \multirow{2}{*}{ Specification } & \multicolumn{2}{|c|}{ Groups } & \multirow{2}{*}{ SEM } \\
\hline & I & II & \\
\hline \multicolumn{4}{|l|}{$\begin{array}{l}\text { Body weight } \\
\text { at weeks: }\end{array}$} \\
\hline 5 & $1.47^{\mathrm{B}}$ & $1.57^{\mathrm{A}}$ & 0.142 \\
\hline 7 & $3.28^{\mathrm{B}}$ & $3.40^{\mathrm{A}}$ & 0.280 \\
\hline 11 & $6.78^{B}$ & $7.20^{A}$ & 0.566 \\
\hline 16 & $13.01^{\mathrm{B}}$ & $13.57^{\mathrm{A}}$ & 0.863 \\
\hline 18 & $14.74^{\mathrm{B}}$ & $15.61^{\wedge}$ & 1.052 \\
\hline$\%$ of total & 100 & 105.9 & \\
\hline \multicolumn{4}{|c|}{$\begin{array}{l}\text { Feed conversion ratio } \mathrm{kg} / \mathrm{kg} \\
\text { weeks: }\end{array}$} \\
\hline $0-5$ & 1.66 & 1.63 & 0.045 \\
\hline $0-7$ & 1.64 & 1.66 & 0.044 \\
\hline $0-11$ & 1.91 & 1.79 & 0.055 \\
\hline $0-16$ & 2.29 & 2.10 & 0.122 \\
\hline $0-18$ & 2.62 & 2.45 & 0.120 \\
\hline$\%$ of total & 100 & 93.5 & \\
\hline \multicolumn{4}{|l|}{$\begin{array}{l}\text { Mortality, \% } \\
\text { wecks: }\end{array}$} \\
\hline $0-1$ & 7.8 & 0.98 & \\
\hline $2-18$ & 4.9 & - & \\
\hline $0-18$ & 12.7 & 0.98 & \\
\hline \multicolumn{4}{|l|}{$\begin{array}{l}\text { Culling } \\
\text { weeks: }\end{array}$} \\
\hline $0-1$ & - & - & \\
\hline $2-18$ & 4.9 & 3.9 & \\
\hline $0-18$ & 4.9 & 3.9 & \\
\hline
\end{tabular}

${ }_{A . B}$ - mean values in the rows with different letters were significantly different at $\mathrm{P}<0.01$ 
charcoal-supplemented feed used on average $6.5 \%$ less feed per kilogram gain than the birds in the control group. We noticed a similar tendency in studies on charcoal supplementation of broiler chickens (Majewska et al., 1999), where $0.3 \%$ charcoal was also added to feeds. Edrington et al. (1997) using superactivated charcoal (SAC) in feeding broilers found that after only 21 days the chickens had $4.6 \%$ higher body weight. The authors attributed this effect to the presence of available microelements and the detoxicating effect of charcoal.

The influence of charcoal supplementation on survival is noteworthy (Table 2). Although no diseases were observed during the experiment, mortality of the control birds was $12.7 \%$, whereas in the experimental group deaths were observed in only one repetition, which accounted for $0.98 \%$ of the entire group. Culling in this group was also lower and equaled $1 \%$ despite the density in it being greater because of lack of mortality. These results point to the beneficial effect of charcoal on the health of birds, which has a decisive impact on the economics of production and meat quality. The European Production Index for the control group was 393, whereas in the experimental group it was much higher and equaled 504 points.

The addition of charcoal did not significantly affect the results of carcass analysis, but did significantly increase the crude protein content in breast muscle by $0.44 \%(\mathrm{P}<0.05)$ (Table 3$)$.

Although the haematological and biochemical blood indicators did not differ significantly, a beneficial trend of added charcoal on the analyzed parameters was seen (Table 4).

TABLE 3

Chemical composition and physical and chemical properties of breast muscle of turkey-toms after $18^{\text {"l }}$ weeks

\begin{tabular}{lccc}
\hline \multirow{2}{*}{ Indices } & \multicolumn{2}{c}{ Groups } & SEM \\
\cline { 2 - 3 } & I & II & \\
\hline Dry matter, \% & 26.98 & 27.27 & 0.240 \\
Crude protein, \% & $23.60^{\circ}$ & $24.04^{\circ}$ & 0.515 \\
Crude fat, \% & 1.27 & 1.17 & 0.478 \\
Crude ash, \% & 1.19 & 1.22 & 0.050 \\
& & & \\
Water holding capacity, $\mathrm{cm}^{2}$ & 6.73 & 7.19 & 1.562 \\
Colour, \% & 24.50 & 23.83 & 2.103 \\
pH 24 h & 5.68 & 5.63 & 0.060 \\
\hline
\end{tabular}

a.b - mean values in the rows with different letters were significantly different at $\mathrm{P}<0.05$ 
TABLE 4

Hacmatological and biochemical indices of blood of turkeys at $18^{\text {th }}$ week

\begin{tabular}{|c|c|c|c|}
\hline \multirow{2}{*}{ Indices } & \multicolumn{2}{|c|}{ Groups } & \multirow{2}{*}{ SEM } \\
\hline & I & II & \\
\hline Red blood cells, $10^{[2 /]}$ & 2.13 & 2.19 & 0.061 \\
\hline White blood cells, $10^{9} / 1$ & 18.00 & 18.50 & 1.955 \\
\hline Hacmog]obin, $g / d$ ] & 10.07 & 11.30 & 0.616 \\
\hline Haematocrit, \% & 33.70 & 35.00 & 1.647 \\
\hline Glucose, $\mathrm{mg} / \mathrm{dl}$ & 180.00 & 170.60 & 28.218 \\
\hline Total protcin, g/dl & 4.16 & 3.78 & 0.385 \\
\hline Cholesterol, mg/dl & 154.20 & 146.60 & 16.848 \\
\hline
\end{tabular}

\section{CONCLUSIONS}

The addition of charcoal in an amount of $3 \mathrm{~kg}$ per ton of feed improved the performance of meat turkeys, reduced mortality and increased the crude protein content in breast muscles.

\section{REFERENCES}

Anjaneyulu Y., Rao P.R., 1993. Experimental aflatoxicosis and its amelioration by activated charcoal in broiler chickens: a pathological study. Indian J. Vet. Pathol. 17 (9), 122-125

Edrington T. S., Kubena L.F., Harley R.B., Rottinghaus G.E., 1997. Influence of a superactivated charcoal on the toxic effects of aflatoxin or T-2 toxin in growing broilers. Poultry Sci. 76, 12052011

Garwacki S., Wiechetek M., 1998. General Veterinary Toxicology (in Polish). Warsaw Agricultural University Press, Warsaw

Grau R., Hamm R., 1953. Über das Wasserbindungs Vermögen des toten Saugetiermuskels. I Mitleilung. Der Einfluss des pH-Wertes auf die Wasserbindungs von zerkleinertem. Rinder Muskel. Biochem. 1, 325-328

Kortz J., Różyczka J., Grajewska-Kołaczyk S., 1968. Methodical aspects of the objective determination of colour in fresh pork meat. Rocz. Nauk rol. B-90 (3), 333-344

Majewska T., Zaborowski M., Zalewski K., 1999. Effect of feed supplementation with charcoal on production results of broiler chickens. (in Polish) Zesz. Nauk. Prz. hod. 45, 371-378

Mikołajczak J., 1993, Stat 1 (in Polish). Agricultural and Technical University Press, Olsztyn

Shareef A.M., Al-Jubory K.M.T., Hassan M.G., 1998. Effect of activated charcoal in reducing dietary aflatoxin-induced stress in broiler chicks. Iraqi J. Vet. Sci. 11 (1), 23-29 


\section{STRESZCZENIE}

\section{Wplyw zastosowania dodatku węgla drzewnego na wyniki produkcyjne ciężkich indorów rzeźnych Big 6}

Doświadczenie przeprowadzono na 204 ciężkich indorach rzeźnych Big 6. Jednodniowe pisklęta podzielono na dwie grupy żywieniowe, w każdej po trzy powtórzenia po 34 ptaki. Wszystkie ptaki żywiono jednakowymi granulowanymi mieszankami standardowymi w systemie 3-stopniowym. Ptaki grupy kontrolnej otrzymywały mieszanki bez dodatku, ptaki z grupy doświadczalnej z dodatkiem rozdrobnionego węgla $\mathrm{z}$ drzew liściastych, w ilości $3 \mathrm{~kg}$ /tonę zadawanej paszy. Węgiel drzewny podawano od pierwszego dnia życia przez cały okres odchowu.

Zastosowany dodatek węgla drzewnego wywarł korzystny wpływ na wyniki produkcyjne. Indory otrzymujące paszę z dodatkiem węgla drzewnego po 18 tygodniach odchowu były cięższe o $870 \mathrm{~g}$, tj. o $5,9 \%$ i lepiej wykorzystywały paszę na $1 \mathrm{~kg}$ przyrostu, o $6,5 \%$, w porównaniu z grupą kontrolną. Przeżywalność ptaków otrzymujących węgiel drzewny wynosiła 99\%, kontroInych $87,3 \%$. W mięśniach piersiowych ptaków doświadczalnych istotnie zwiększyła się zawartość białka ogólnego. Wskaźnik Europejskiego Indeksu Produkcyjnego wynosił dla grupy kontrolnej 393, dla grupy otrzymującej dodatek węgla drzewnego 504 punkty. 